слід розглядати як «лесирування» (накладання тонкого шару прозорих, чи напівпрозорих фарб на просохлу поверхню) - технічний прийом живопису, який належить до механічного способу змішування. Натомість, прикладом оптичного змішування в цій підгрупі може бути техніка «мармурування», яка з'явилася внаслідок появи текстильних барвників, що мають вигляд різноманітних фарбових сполук, що дозволяють одномоментно відтворювати багатоколірні фактурноколористичні поєднання.

У підсумку слід відзначити, що запропонована проекція теоретичних питань кольорознавства на мистецькі практики сучасного художнього текстилю в жодній мірі не обмежує простір можливих сфер «прикладного кольорознавства». Разом з тим, вона засвідчує емоційносмислову поліфонічність сучасних текстильних практик, які можуть відтворити будь яку авторську ідею за допомогою широкого спектру кольороутворення за допомогою текстильних носіїв кольору.

\title{
Література:
}

1. Балека Я. Синий - цвет жизни и смерти. Метафизика цвета. М: Исусство-XXI век, 2008.410 с.

2. Печенюк Т. Кольорознавство. К: «Грані-Т», 2009, 198 с.

DOI https://doi.org/10.30525/978-9934-26-004-9-61

\section{М. І. РОСТОВЦЕВ ЯК ДОСЛІДНИК АНТИЧНОГО МИСТЕЦТВА ПІВНІЧНОГО ПОНТУ}

\author{
Русясва М. В. \\ кандидат мистецтвознавства, доцент, \\ доцент кафедри теорії та історії мистецтва \\ Національної академії образотворчого мистецттва і архітектури \\ м. Київ, Украӥна
}

Початок систематичних штудій античного мистецтва Північного Понту припадає на першу третину XX ст. Найбільший внесок на цьому етапі зробив Михайло Іванович Ростовцев (1870-1952) - титан давньої історії, один з видатних науковців-істориків XX ст., світовий авторитет 3 елліністичної та римської історії, професор Сльського університету, почесний доктор Оксфорда, Кембриджа i Гарварда, президент Американської історичної асоціації. 
Народився майбутній всесвітньовідомий історик 150 років тому 10 листопада 1870 р. в Житомирі. У цьому місті - «старозавітній цитаделі шкільного класицизму» - він пішов до губернської Житомирської гімназії, якою завідував його батько - дослідник i викладач латини. Невдовзі родина переїхала до Києва, де 1888 р. M. І. Ростовцев закінчив зі срібною медаллю Першу гімназію. Тут він досконало опанував давньогрецькою і латиною, здобув знання 3 античної літератури, розвинув володіння розумовим інструментарієм при аналізі складних текстів [1, с. 45-46]. У 1888-1890-му pp. на класичному відділенні Університету Св. Володимира в Києві він слухав лекції Ю.А. Кулаковського, А. І. Сонні, Й. Е. Леціуса, В. Б. Антоновича [2, с. 51-52]. Два наступних роки припали на навчання в СанктПетербурзькому університеті, де своїми головними наставниками він назвав Т. Ф. Зелінського та Н. П. Кондакова [1, с. 46]. Від першого Ростовцев успадкував широту поглядів і зухвалу постановку проблем у галузі античної історії, досконалі знання античної літературної традиції, вміння представити творчість стародавніх письменників у контексті ідей та настроїв, характерних для їхньої епохи; другий - відкрив для нього світ класичної археології та мистецтва, долучив до таїнства іконографічного аналізу [2, с. 53-54; 11, с. 233-235; 12, с. 355-356]. Важливим етапом у становленні М. І. Ростовцева не тільки як історика та археолога, але i як мистецтвознавця було стажування в провідних європейських наукових центрах (1895-1898). На основі здобутих знань, синтезу ідей і методів, він розробив свій власний новаторський метод дослідження античного мистецтва, що значно випередив його епоху.

Праці М. І. Ростовцева 3 історії мистецтва Північного Понту різноманітні і розділені нами за основними темами на три умовні групи: монументальний живопис, елліно-скіфське мистецтво, скіфо-сибірський звіриний стиль. Всі вони носять передусім концептуальний історичний характер, оскільки науковець розглядав зміни іконографії та стилю в якості симптому історичних процесів.

Особливе місце в його науковому доробку посідає античний декоративний стінопис, захоплення яким почалося ще в студентські роки під впливом Н. П. Кондакова. Близьке знайомство 3 Помпеями, закоханість у це місто та його пам'ятки, тривале спілкування 3 А. Мау, котрий виділив чотири стилі помпеянських розписів, i всіляко підтримував молодого колегу [11, с. 239-242], інтерес до класичних старожитностей батьківщини [1, с. 46], сприяли вибору цієї теми як першої магістральної галузі його багаторічних досліджень.

Вже у перших статтях М. І. Ростовцев відзначив, що пантикапейські склепи мають суто елліністичний характер розпису [4, с. 296; 5, с. 100], багаті живописом релігійного змісту, який допомагає розумінню 
світогляду боспорян в епоху еллінізму i Риму [6, с. 119]. У фундаментальній монографії на основі залучення широкого кола джерел 3 усієї античної ойкумени і грунтовного аналізу пам'яток Боспору, Ольвії та Херсонеса він дослідив історію античного декоративного живопису загалом [8]. Ця праця не втратила своєї актуальності, що, зокрема, засвідчує іï нещодавній французький переклад [16].

Вивчення історії Скіфії та Боспору - новий період у науковій діяльності М. І. Ростовцева, що розпочався 1909 р. На основі мистецтвознавчих методів аналізу та інтерпретації стародавніх пам'яток він виробив своє нетрадиційне розуміння іранізму скіфів. Досліджуючи природу державної влади Скіфії і Боспору за доби еллінізму і маючи в своєму розпорядженні лише твори торевтики IV ст. до н. е., науковець на підставі іконографічного аналізу сакральних сцен інтерпретував їх сюжети як інвеституру царя богом-вершником, підкреслюючи їх релігійний характер [7].

У фундаментальному джерелознавчому дослідженні «Скифия и Боспор. Критическое обозрение памятников литературных и археологических» М. І. Ростовцев, звернувшись до зображень скіфів на виробах із коштовних металів, вперше ввів поняття «елліно-скіфське мистецтво» $[10$, с. $161-176,439,440]$, яке й до сьогодні використовується в науці. На підставі сюжетно-стилістичного аналізу цих творів i зіставлення їх 3 карбуванням монет у Пантикапеї висловлено припущення про їх місцеве (боспорське) походження [10, с. 446].

Сто років тому, в 1920 р. розпочався американський, останній період у житті і науковій творчості М. І. Ростовцева, який зробив його класиком світового антикознавства, оскільки саме в США він отримав найсприятливіші умови для наукової роботи [13, p. 92]. Продовжуючи дослідження елліно-скіфського мистецтва, він наголошував, що переважну більшість предметів кінця V-IV ст. до н. е. прикрашено абсолютно новими для грецького мистецтва композиціями та іконографічними образами, що виконані у стилі «етнографічного реалізму» і $з$ достовірністю передають зовнішній вигляд скіфів; деякі 3 них схожі на ілюстрації до Геродота, інші - Ефора; грецькі торевти на замовлення скіфів створили предмети, на яких відтворено сцени 3 релігійного, економічного і соціального життя скіфів тощо [14; 15$]$.

M. І. Ростовцеву, як одному 3 основоположників сучасного скіфознавства, також належить пріоритет в ідентифікації, систематизації та типології зображень скіфо-сибірського звіриного стилю [9; 10; 14; 15], який, на його думку, був «найдавнішим декоративним мистецтвом в історії людства» $[15$, р. 4]. Науковець визначив чотири стадії скіфської історії, виявив дванадцять початкових ознак скіфо-сибірського звіриного стилю, що притаманні для архаїчного періоду скіфської історії, а також 232 
вперше представив його подальшу еволюцію [15]. Погляди М. І. Ростовцева на джерела походження скіфського звіриного стилю протягом часу зазнали істотних змін [пор.: 9, с. 43-45; 10, с. 307-308, $337 ; 14$, p. 193, 197; 15, p. 64-67, 73-74] і справили великий вплив на дослідників [3, с. 29-30, 1006-1015].

Отже, концептуальний склад розуму М. І. Ростовцева збагатив дослідження античного мистецтва новими ідеями. Він не тільки розширив джерелознавчу базу, але й відкрив нові можливості інтерпетації творів мистецтва. Не всі його висновки і гіпотези витримали випробування часом, адже за останнє століття накопичено колосальний новий матеріал з історії мистецтва скіфів та греків. Низка висловлювань М. І. Ростовцева вимагає уточнень і перегляду. Тим не менш більшість його концепцій - це сучасний стандартний підхід до припонтійського античного мистецтва. Отже, інтерпретація і сприйняття М. І. Ростовцевим монументального стінопису, елліно-скіфського мистецтва і скіфського звіриного стилю загалом були вірними і передбачили багато досягнень сучасної науки.

\section{Література:}

1. Бонгард-Левин Г. М. Автобиографические материалы М. И. Ростовцева. Бонгард-Левин Г. М. (ред.). Скифский роман. Москва: Роспэн, 1997. С. 43-49.

2. Зуев В. Ю. М. И. Ростовцев. Годы в России. Биографическая хроника. Бонгард-Левин Г. М. (ред.). Скифский роман. Москва: Роспэн, 1997. C. $50-83$.

3. Канторович А. Р. Скифский звериный стиль Восточной Европы: классификация, типология, хронология, эволюция : дис. ... д-ра ист. наук: 07.00.06. Москва, 2015. 1724 с.

4. Ростовцев М. И. Заметка о росписях керченских катакомб. Записки Императорского русского археологического общества. 1897. Т.9. Вып. 3/4. С. 291-298.

5. Ростовцев М. И. Эллинистическо-римский архитектурный пейзаж. Записки Классического отделения Императорского русского археологического общества. 1910. Т. 6. С. 1-143.

6. Ростовцев М. И. Роспись Керченской гробницы, открытой в 1891 году. ПРОЕАР $\triangle \triangle \Omega P O N$. Санкт-Петербург: тип. В. Ф. Киршбаума, 1911. С. 119-154.

7. Ростовцев М. И. Представление о монархической власти в Скифии и на Боспоре. Известия археологической комиссии. 1913. Вып. 49. C. $1-62$.

8. Ростовцев М. И. Античная декоративная живопись на юге России. Санкт-Петербург.: Изд-во Императорской археологической комиссии. 
Атлас. 1913. 112 с. Т. 1: Описание и исследование памятников. Текст. 1914. $537 \mathrm{c}$.

9. Ростовцев М. И. Эллинство и иранство на юге России. Петроград: Огни, 1918. $190 \mathrm{c.}$

10. Ростовцев М. И. Скифия и Боспор. І. Критическое обозрение памятников литературных и археологических. Петроград: Изд-во Российской Академии истории материальной культуры, 1925. $621 \mathrm{c}$.

11. Тункина И. В. М. И. Ростовцев на перекрестке между русской и немецкой классической археологией до Первой мировой войны. Scripta antiqua. 2015. T. 4. С. 231-262.

12. Фролов Э. Д. Русская наука об античности: Историографические очерки. Санкт-Петербург: Изд-во СПБУ, 1998. 522 с.

13. Momigliano A. D. M. I. Rostovtzeff. Studies in Historiography. London: Weidenfeld \& Nicolson, 1966. P. 91-104.

14. Rostovtzeff M. Iranians and Greeks in South Russia. Oxford: The Clarendon Press, 1922. XV. 260 p.

15. Rostovtzeff M. The Animal Style in South Russia and China. Princeton: University Press, 1929. XVI. 112 p.

16. Rostovtzeff M. I. La peinture décorative antique en Russie Méridionale. A. Barbet (dir.). Paris: Académie des Inscriptions et Belleslettres, 2003-2004. 716 p.

DOI https://doi.org/10.30525/978-9934-26-004-9-62

\title{
РЕПРОДУКЦІЯ ФОТОГРАФІЇ: ФОТОТИПІЯ ТА ГЕЛЕОТИПІЯ. РЕСТАВРАЦІЯ АЛЬБОМУ ГЕЛЕОТИПІВ «LA DÉCORATION ET L'AMEUBLEMENT À L'EXPOSITION DE 1900: SERIE 2»
}

\author{
Садикходжаєва А. О. \\ молодший науковий співробітник \\ Наукової бібліотеки \\ Львівського начіонального університету імені Івана Франка \\ м. Львів, Украӥна
}

Фоторепродукції являють собою не лише результат технічного i наукового прогресу, а також $є$ віддзеркаленням певного періоду існування людства, важливим носієм візуальної інформації і мистецьким об’єктом. Винахід фоторепродукцій та їх розповсюдження як колекцій художніх творів або як збірок наукових ілюстрацій тощо, показують 